トピックス

\title{
視運動性反応の初期成分
}

\author{
清水 直樹
}

\section{Initiation of the optokinetic response}

\author{
Naoki Shimizu \\ Department of Otolaryngology-Head and Neck Surgery, \\ Nara Medical University
}

\section{はじめに}

頭部運動時に良好な視覚を得るためには, 前庭 器が体の動きを感知し, 瞬時に前庭動眼反射をお こして網膜上の像のブレを打ち消すとともに, 視 運動性眼球運動が相補的に働くことが重要であ る。視運動性眼球運動のうち, 視運動性反応 $(\mathrm{Op}-$ tokinetic response; OKR) は, 視覚刺激に対す る反応様式の違いから, 初期に急速増加する成分 と緩やかに定常状態に達する応答成分の 2 つの成

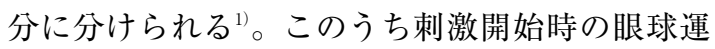
動成分は, 生体の精緻な感覚 - 運動制御機構を行 動学的に理解するアプローチの一つとして, 基礎 分野を中心に研究されている (図 1$)^{2) \sim 3)}$ 。一方, 刺激開始後数秒〜数十秒後以降の反応である定常 成分の眼球運動の観察は, 平衡機能検査の 1 つで ある視運動性眼振検査として広く臨床応用されて いる。本稿では，まずこれまで霊長類を対象とし て研究されてきた OKRの初期成分に関する基本 的性質を述べ，次に近年明らかとなってきたマウ スで得られた知見について述べる。

\section{OKR の初期成分について}

日常診療で行われる視運動性眼振検査は, 被験 者の周りに縞模様のドラムを回転させることで誘 発される眼球運動を観察している。この眼球運動 は視覚刺激の移動方向へ向かう緩徐相と逆方向へ 向かう急速相から構成される。視覚の安定化には

奈良県立医科大学耳鼻咽喉 - 頭頸部外科学講座
緩徐相の眼球運動が重要であるが, 緩徐相はさら に初期の加速の大きい成分（初期成分）とそれに 続く速度変化の少ない成分に分けられる（定常成 分)。ヒトの場合，刺激開始後 200 ミリ秒以内に誘 発される眼球位置の変化は約 0.25 度と極めて小さ く, 計測にはサーチコイルを使用した電磁誘導式 眼位計測システムが一般的である。しかしなが ら, このサーチコイル法は被験者に負担を強いる こともあり, この分野での臨床研究は少なく, 耳 鼻科領域においてもほとんど注目されてこなかっ た。

OKR の初期成分を観察する実験では，定常成 分を観察する場合と異なり，1トライアルに要す る刺激提示時間は数秒で済むため, 短時間に複数 回の計測ができ，より多くのデー夕を基にした解 析を行うことが可能となる。また, 定常成分の反 応は, 時間経過とともに被検者の集中力や順応な ど様々な高次の要素が測定結果に影響する可能性 があるのに対し，初期の応答成分では，単純な反 射としての反応が観察でき, 比較的単純な運動制 御機構として, 視覚入力が眼球運動を駆動する際 の脳内での純粋な感覚 - 運動情報処理機構の評価 ができる。

この初期成分の眼球運動に関する研究は, 霊長 類を用いた神経生理学的研究を中心に, 神経科学 の様々な分野で報告されている。霊長類の初期成 分の発現に関与する神経回路は詳細に調べられて おり, 網膜が検出した視覚信号の主要な伝達経路 
A

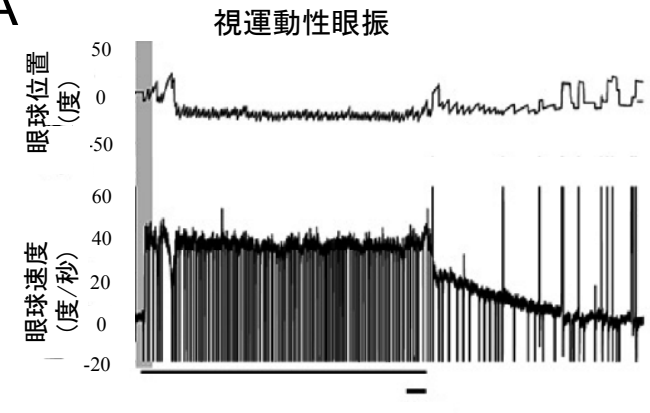

B
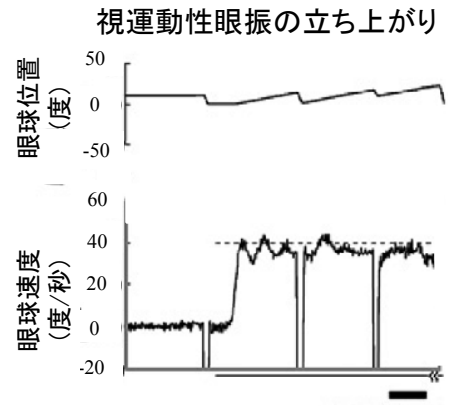

100 ミリ秒

図 1 視運動性眼振と視運動性反応の初期成分の関係

A. 40 度/秒で右方向に動く視覚刺激を 15 秒間点灯して誘発したサルの視運動性眼 振。B．視運動性眼振の立ち上がり部位（Aの影の部位）を拡大した図。それぞれ 上段が水平方向の眼球位置，下段が眼球速度，太線が視覚刺激を点灯していた時間 を示す。文献 3 ）より許可を得て転載。

は外側膝状体に伝わり，大脳皮質第一次視覚野か ら, 高次視覚野の MT 野 (middle temporal area), MST 野 (medial superior temporal area) などの 運動視に関与する領域を経て, 橋核や小脳に到達 し, 感覚情報が運動指令へと変換され, 眼球運動 が駆動されると考えられている2 市。これに対し 定常成分の発現に関する神経回路は, 網膜から視 索核および副視索系を通る皮質下の経路が考えら れており, 様々な動物種にも共通してみられる系 統発生上，古い経路である5)。

\section{霊長類以外の動物での研究}

近年の遺伝子工学の発達に伴い, 視覚, 前庭機 能に関わる多様な遺伝子変換マウスを扱う実験が 可能となり, また，これまで以上に複雑な刺激提 示システムや正確な眼球運動計測装置を用いたマ ウスの眼球運動に関する研究が増加している ${ }^{6}$ 。 霊長類と比較し大脳皮質が十分に発達していない マウスにおいて, 初期成分の眼球運動に関して は, 定常成分の応答特性と比べ良く分かっていな い。しかし, 近年, マウスでも適切な視覚刺激を 用いることで, OKRの初期成分を観察すること が可能であることが報告されている7。

我々は以下のような方法を用いてマウスを用い た OKRの初期成分を観察した ${ }^{8)}$ 。頭部を固定し たマウスの周囲にコンピューターモニターを設置 した。あらかじめ作成した視覚刺激をモニター上 に提示し, 一定速度で水平移動させた。各視覚刺 激に対する眼球運動は, 赤外線カメラで計測しオ
フラインで解析を行った。なお，この実験システ ムは定常成分の眼球運動を観察する際にも, 従来 用いられてきた回転ドラムの代わりにコンピュー ターモニターを使用することにより，プログラム 制御された複雑な視覚刺激の提示が可能となる。

OKRの初期成分については, 黒白の縞模様を 用いた実験で黒白の幅が 8 度, 移動速度が 12 度 秒の刺激が最も大きな反応応答を示す最適刺激で あることが報告されており 激を用いて誘発した眼球運動の例を示す。刺激が 動き始めてから 100 ミリ秒という非常に短い潜時 で眼球運動が開始していることがわかる。視覚刺 激に対して眼球運動が誘発されると, 網膜上の視 覚刺激の動く速度は眼球運動の影響を受けること になる。この眼球運動の影響が現れるまで，つま り, 眼球運動の潜時の 2 倍の期間はフィードバッ クが影響する前のオープンループ状態と考えられ る。この部分の眼球運動を OKR の初期成分とし て特に注目して解析した。

この刺激開始後 200 ミリ秒以内の早い応答成分 に注目すると, マウスでも霊長類同様, 帯状の小 範囲の視覚刺激に対し一過性の眼球運動が観察さ れた。マウスでは霊長類と異なり網膜中心窩が発 達していないため, これまでの研究では広範囲の 視覚刺激を用いて, 受容野全体を一様に刺激する 実験が中心で，小範囲の視覚刺激では眼球運動は 誘発されないと考えられていた。上下幅（視角 5 度）を一定にした帯状の縞模様の提示する部位 


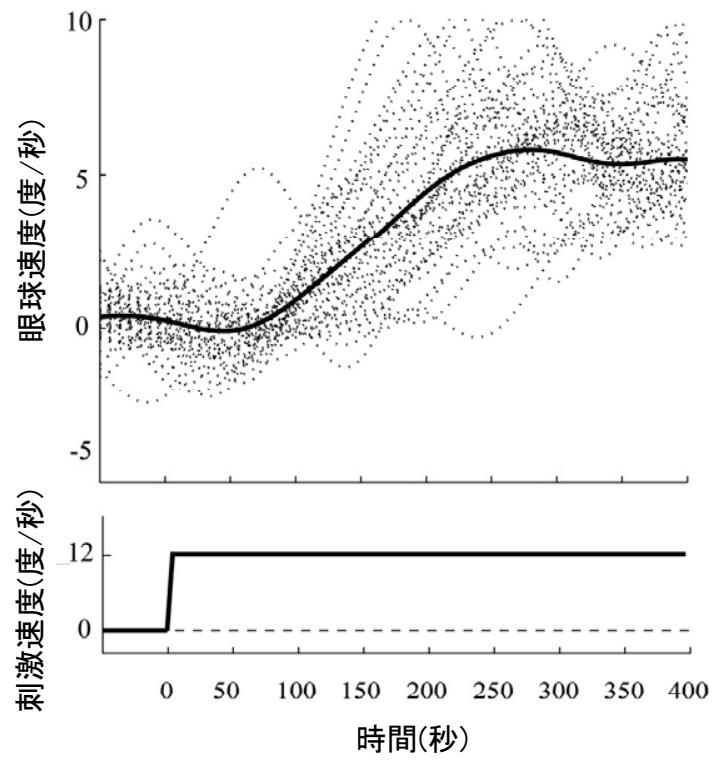

図2 マウスで誘発された視運動性反応の初期成分 12度/秒で耳側から鼻側方向に水平移動する 視覚刺激で誘発した視運動性反応の初期の応 答成分。上段が誘発された眼球速度（点線は 各試行ごとの反応, 実線は平均眼球速度), 下段が視覚刺激速度を示す。

を, 水平位置より-10から 35 度で変化させた際に 誘発される反応の解析を行ったところ, 水平位置 より上方 $25^{\circ}$ の部分に一致して反応応答が良いこ とが明らかになった（図 3 )。さらに, 眼底カメ ラを用いて眼位を計測した結果, 最適反応を示す 受容野は網膜上の神経節細胞密度の濃い領域と一 致することが示され, マウスでも外界の刺激に対 する視野感度依存性を持つことが推測された ${ }^{8)}$ 。 すなわち OKR の初期成分に注目することで，こ れまでマウスでは検証されていなかった中心ー周 辺視野分離刺激など, 霊長類と同様の複雑な視覚 刺激を用いた研究が可能であることが示唆され た。

これらの研究結果から, 霊長類の初期成分の発 現に関与する神経機構の原始的なものがマウスに も存在することが考えられるが, 霊長類とは異な る反応様式も明らかになりつつある。例えば, 刺 激提示範囲を変化させた場合, ヒトでは刺激面積 が小さい場合でも広範囲の刺激と同等の反応特性 を示すのに対し, マウスでは刺激範囲の増加に伴 って強い反応応答が観察されることなどが報告さ

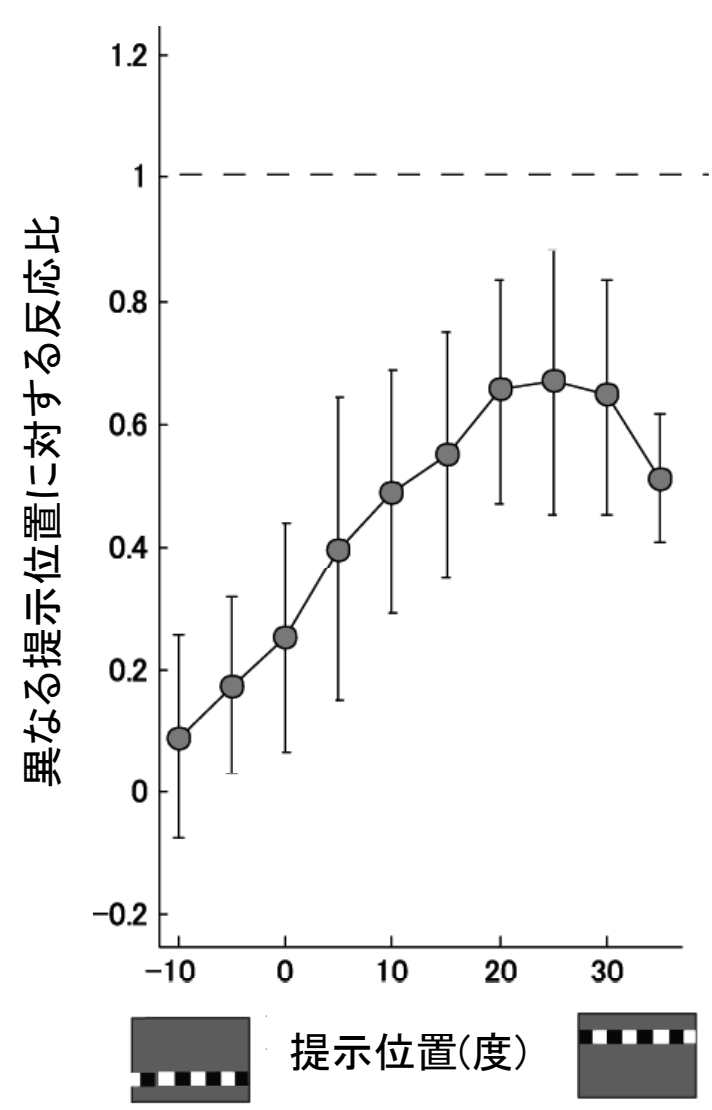

図3マウスにおける視野感度特性

刺激提示位置を変化させて誘発した視運動性 反応の初期成分の比較。全画面刺激に対する 反応を 1 として示す。マウス 8 匹の反応の平 均値。

れている9)。また霊長類と比較し，マウスにおい て初期成分が関与する神経回路の検証も十分とは 言えず，サルと同様の電気生理学実験および中継 路の破壊実験による神経生理学的な検証が今後の 課題である。

\section{初期成分と前庭系}

前庭刺激に反応する前庭神経核ニューロンが,

OKR 引き起こす視覚刺激にも反応することな どから，前庭神経核は OKRの発現に関与する重 要な中継核であると考えられている。初期成分と 前庭系に関する報告として, 前庭系は OKR の遅 い成分に深く関与しているが, 初期成分の発現に 対する寄与は相対的に小さいと考えられてお $り^{10)}$, また, 迷路破壊により前庭機能を低下させ 
ても視運動性眼振の初期成分は誘発されることが 知られている ${ }^{1112)}$ 。一方, マウスと同じ側眼動物 であるウサギでは，両側迷路の破壊を行うと，末 梢前庭からの入力が失われることにより, 前庭神 経核ニューロンの活動性が減少し, 前庭動眼反射 とともに視運動性眼振はほぼ消失する ${ }^{13)}$ 。ウサギ やマウスでは網膜内の神経回路で視覚刺激の動き を検出していることが報告されており，霊長類と は大きく異なる神経機構の存在も推測されてい る ${ }^{14)}$ 。しかしながら, OKRの定常成分と比較す ると初期成分と前庭系の関与は十分に検証されて いるとは言えず，初期成分に対する前庭系の関与 に関する平衡医学領域での研究が待たれる。今 後, 初期成分に注目した研究を進めていくこと で，従来の定常成分の観察では検出できなかった 異常眼球運動を呈する患者の病態解明や，責任病 変の局在診断におけるスクリーニング的な新たな 平衡機能検查の開発に貢献できることが期待され る。また，引き続きマウスにおける基礎的知見を 蓄積し, 霊長類では不可能であった遺伝子工学的 手法を応用した眼球運動実験系を構築していくこ とで, 視覚系と前庭系が関与する眼球運動制御機 構の解明につながるものと期待される。

\section{文 献}

1) Cohen B, Matsuo V, Raphan T: Quantitative analysis of the velocity characteristics of optokinetic nystagmus and optokinetic afternystagmus. J Physiol 270: 321-344, 1977

2) Kawano K: Ocular tracking: behavior and neurophysiology. Current Opinion in Neurobiology 9: 467-473, 1999

3 ）竹村 文, 河野憲二 : 前庭動眼反射の視覚的 バックアップ機構. Equilibrium Res 70: 95103, 2011

4) Kawano K, Shidara M, Watanabe Y, et al.: Neural activity in cortical area MST of alert monkey during ocular following responses. J Neurophysiol 6: 2305-2324, 1994

5 ) Wallaman J: Subcortical optokinetic mecha- nisms. Rev Oculomot Res 5: 321-342, 1993

6 ) Stahl JS: Characteristics and applications of mouse eye movements. In eds Chalupa LM, Williams R. Eye, retina, and the visual system of the mouse. MIT press 87-105, 2008

7 ) Tabata H, Shimizu N, Wada Y, et al.: Initiation of the optokinetic response (OKR) in mice. J Vis 10: 1-17, 2010

8 ) Shimizu N, Tabata H, Wada Y, et al.: Distribution of optokinetic sensitivity across the retina of mice in relation to eye orientation. Neuroscience 168: 200-208, 2010

9 ) Sheliga BM, FitzGibbon EJ, Miles FA: Human ocular following: evidence that responses to large-field stimuli are limited by local and global inhibitory influences. Prog Brain Res 171: 237-243, 2008

10) Lisberger SG, Miles FA, Optican LM, et al.: The optokinetic response in monkey: underlying mechanisms and their sensitivity to long-term adaptive changes in vestibuloocular reflex. J Neurophysiol 45: 869-890, 1981

11) Cohen B, Uemura T, Takemori S: Effects of labyrinthectomy on optokinetic nystagmus $(\mathrm{OKN})$ and optokinetic after-nystagmus (OKAN). Int J Equilibrium Res 1: 88-93, 1973

12) Zee DS, Yee RD, Robinson DA: Optokinetic responses in labyrinthine-defective human beings. Brain Res 2: 423-428, 1976

13) Collewijn H: Impairment of optokinetic (after-) nystagmus by labyrinthectomy in the rabbit. Exp Neurol 1: 146-156, 1976

14) Yoshida $K$, Watanabe $D$, Ishikane $H$, et al.: A key role of starburst amacrine cells in originating retinal directional selectivity and optokinetic eye movement. Neuron 3: 771-780, 2001 